\title{
Erratum to: Feasibility, acceptability and potential effectiveness of dignity therapy for family carers of people with motor neurone disease
}

\author{
Brenda Bentley*, Moira O'Connor, Lauren J. Breen and Robert Kane
}

\section{Erratum}

The acknowledgement of our article [1] published in $B M C$ Palliative Care has been incorrect with respect to the contributions of Samar Aoun and Harvey Max Chochinov who also contributed to the conception and design of the project. The corrected acknowledgement is presented here.

\section{Acknowledgement}

The authors thank Samar Aoun and Harvey Max Chochinov for their assistance with the project, for securing the funding for this study, and acknowledge their contribution to the conception and design of the project. We are grateful for the support of the Motor Neurone Disease Association of Western Australia. Finally, we wish to thank all of the people who took part in this study.

\section{Editorial note}

The editorial department of BMC Palliative Care would like to inform its readers that the corresponding author has changed affiliation since the publication of the original article [1] and can now be contacted via b.bentley@murdoch.edu.au.

Received: 8 January 2016 Accepted: 8 January 2016

Published online: 17 February 2016

\section{Reference}

1. Bentley B, O'Connor M, Breen $\sqcup$, Kane R. Feasibility, acceptability and potential effectiveness of dignity therapy for family carers of people with motor neurone disease. BMC Palliat Care. 2014:13:12.
* Correspondence: brenda.bentley@curtin.edu.au

School of Psychology and Speech Pathology, Faculty of Health Sciences, Curtin University, GPO Box U 1987, Perth WA6845, Australia
Submit your next manuscript to BioMed Central and we will help you at every step:

- We accept pre-submission inquiries

- Our selector tool helps you to find the most relevant journal

- We provide round the clock customer support

- Convenient online submission

- Thorough peer review

- Inclusion in PubMed and all major indexing services

- Maximum visibility for your research

Submit your manuscript at www.biomedcentral.com/submit 